Provided for non-commercial research and education use. Not for reproduction, distribution or commercial use.

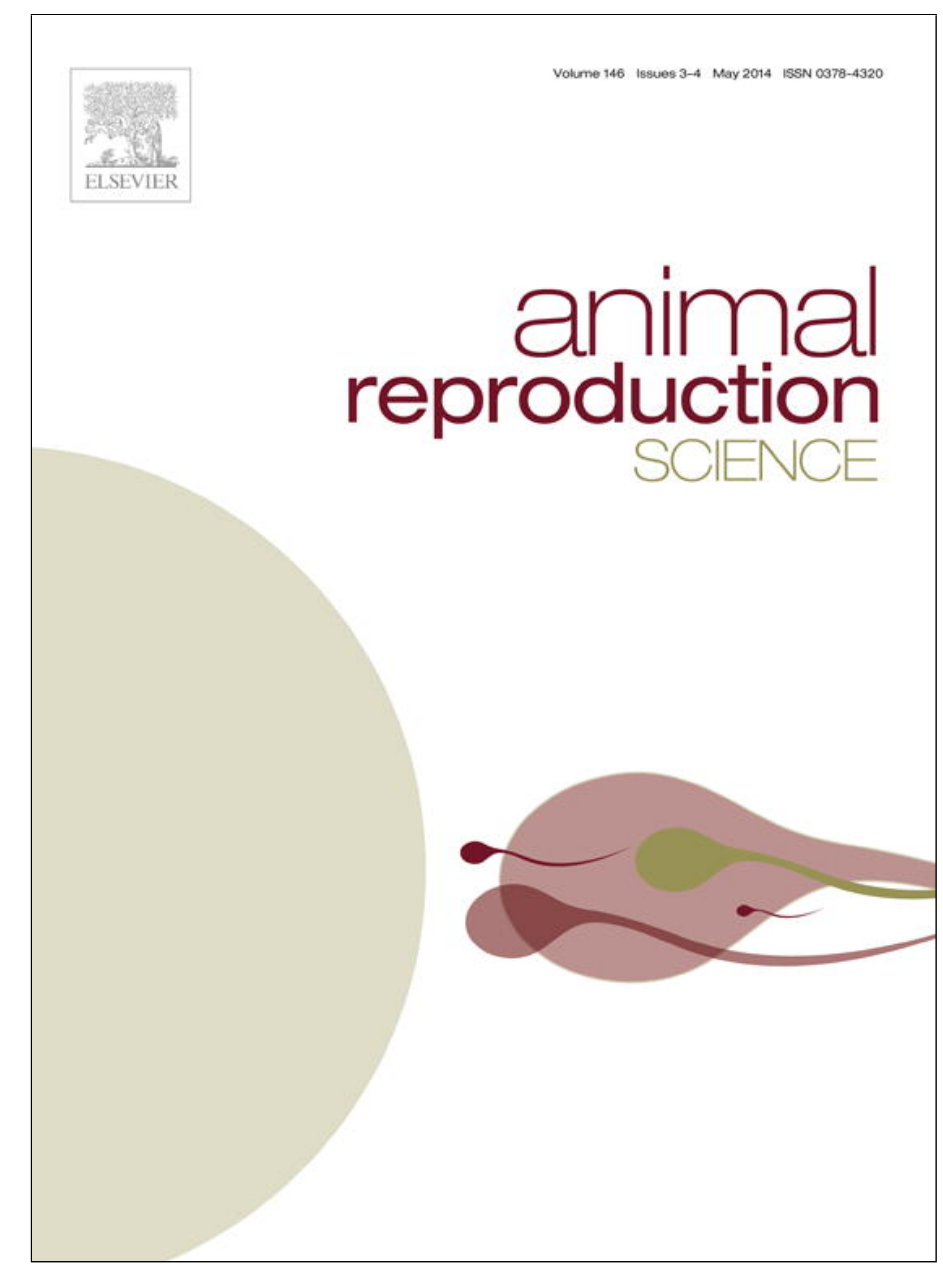

This article appeared in a journal published by Elsevier. The attached copy is furnished to the author for internal non-commercial research and education use, including for instruction at the authors institution and sharing with colleagues.

Other uses, including reproduction and distribution, or selling or licensing copies, or posting to personal, institutional or third party websites are prohibited.

In most cases authors are permitted to post their version of the article (e.g. in Word or Tex form) to their personal website or institutional repository. Authors requiring further information regarding Elsevier's archiving and manuscript policies are encouraged to visit:

http://www.elsevier.com/authorsrights 


\title{
Reproductive long-term effects, endocrine response and fatty acid profile of rabbit does fed diets supplemented with $n-3$ fatty acids ${ }^{\text {负 }}$
}

\author{
P.G. Rebollar ${ }^{\text {a,* }}$, R.M. García-García ${ }^{\mathrm{b}}$, M. Arias-Álvarez ${ }^{\mathrm{c}}$, P. Millán ${ }^{\mathrm{b}}$, A.I. Rey ${ }^{\mathrm{c}}$, \\ M. Rodríguez ${ }^{\mathrm{b}}$, N. Formoso-Rafferty ${ }^{\mathrm{b}}$, S. de la Riva ${ }^{\mathrm{b}}$, M. Masdeu ${ }^{\mathrm{b}}$, \\ P.L. Lorenzo ${ }^{\mathrm{b}}$, P. García-Rebollar ${ }^{\mathrm{a}}$ \\ a Dpt. Producción Animal. ETSI Agrónomos, Universidad Politécnica de Madrid, Ciudad Universitaria, s/n, 28040 Madrid, Spain \\ b Dpt. Fisiología (Fisiología Animal), Facultad de Veterinaria, Universidad Complutense de Madrid, Ciudad Universitaria, s/n, 28040 \\ Madrid, Spain \\ c Dpt. Producción Animal. Facultad de Veterinaria. Universidad Complutense de Madrid. Ciudad Universitaria, s/n, 28040, Madrid, Spain
}

\section{A R T I C L E I N F O}

\section{Article history:}

Received 21 December 2013

Received in revised form 27 February 2014

Accepted 28 February 2014

Available online 12 March 2014

\section{Keywords:}

Rabbits

Progesterone

LH

Productivity

EPA

DHA

\begin{abstract}
A B S T R A C T
The effect of a diet enriched with polyunsaturated $n-3$ fatty acids (PUFA) on endocrine, reproductive, and productive responses of rabbit females and the litters has been studied. Nulliparous does $(n=125)$ were fed ad libitum from rearing to second weaning two diets supplemented with different fat sources: $7.5 \mathrm{~g} / \mathrm{kg}$ lard for the control diet (group C; $n=63$ ) or $15 \mathrm{~g} / \mathrm{kg}$ of a commercial supplement containing a $50 \%$ ether extract and $35 \%$ of total fatty acids (FAs) as PUFA $n-3$ (Group P; $n=62$ ). Dietary treatments did not affect apparent digestibility coefficients of nutrients, or reproductive variables of does including milk production, mortality and average daily gain of kits over two lactations. However, on Day 5 and 7 post-induction of ovulation, progesterone of Group P tended to increase to a greater extent than in does of Group C. Total PUFAs, $n-6$ and $n-3$ and eicosapentanoic (EPA) contents were greater in adipose tissues of does in Group P than in Group C. Docosapentaenoic acid (DPA), EPA, and docosahexaenoic acid (DHA) concentrations were greater in peri-ovarian than in scapular fat with abdominal fat being intermediate in concentration. In PUFA supplemented does, kit mortality at the second parturition tended to be less than in control does. Also, kits born to does of the PUFA-supplemented group weighed more and were of greater length than from does of control group. In conclusion, effectiveness of dietary intervention on reproductive and performance response is greater in the second parity, which suggests an accumulative long-term beneficial effect of $n-3$ FA supplementation in reproductive rabbit does.
\end{abstract}

Published by Elsevier B.V.

\footnotetext{
is Part of this research was presented in XV JORNADAS SOBRE PRODUCCIÓN ANIMAL, ITEA, May 2013.

* Corresponding author: Tel.: +34 914524 868; fax: +34 915499763.

E-mail address: pilar.grebollar@upm.es (P.G. Rebollar).
}

\section{Introduction}

Long chain $n-3$ and $n-6$ polyunsaturated fatty acids (PUFA) have important structural, metabolic and regulatory roles in animals. Concentration of PUFA in vegetable ingredients is minimal and animals have to produce these 
fatty acids from ALA ( $\alpha$-linolenic acid; C18:3 n-3) and LA (linoleic acid; C18:2 n-6), through a complex mechanism of elongation and desaturation, with several competitive limiting steps. This frequently leads to suboptimal concentration of $n-3$ PUFA in cell membranes, which may negatively affect physiological regulation, including reproductive response and newborn survival (for review, see Wathes et al., 2007). The proportions of different PUFA in animal tissues reflect the dietary consumption, and particularly in rabbits, there is the capability of modifying the FA profile through the use of unsaturated dietary fat sources (Hernández et al., 2000; Tres et al., 2008, 2009; Benatmane et al., 2011; Al-Nouri et al., 2012; Dal Bosco et al., 2012; Peiretti, 2012).

Altering the $n-3$ PUFA content in rabbit tissues by dietary intervention has proven to be effective and has important implications related to the health of rabbits and humans who consume animal products (Harris, 2007). The inclusion in rabbit female diets of EPA (eicosapentanoic acid; C20:5n-3) or DHA (docosahexaneoic acid; C22:6n3 ) present in fish products could be a way to improve the reproduction and productivity of these animals as PUFA are involved in both prostaglandin (PG) and steroid metabolism (Wathes et al., 2007). The 1- and 2-series PG are derived from the $n-6$ PUFA, dihomo- $\gamma$-linolenic acid (DGLA; C20:3n-6) and arachidonic acid (AA, C20:4n6 ) respectively, whereas the 3-series PG are derived from EPA (Needleman et al., 1986). A number of trials suggest the ability of $n-3$ PUFA supplements from fish products to reduce 2 -series PG secretion by the endometrium, preventing early embryonic death (Staples et al., 1998; Mattos et al., 2004; Coyne et al., 2008; Santos et al., 2008). Inhibition of endogenous release of AA, however, has direct negative effects on the Steroid Acute Regulator [STAR] protein decreasing steroid synthesis (Wang et al., 2003). Nevertheless, there is considerable but inconsistent information that has been reported about the effect of dietary PUFA $n-3$ supplementation on female reproduction in different species. There is an enhanced ovulatory response by altering PG E production in rats (Trujillo and Beoughton, 1995) and a possible positive influence on ovarian follicles as well as oocyte quality in ewes (Zeron et al., 2002). In cows, decreased progesterone concentrations were observed by Hinckley et al. (1996) and Hutchinson et al. (2012) but inconsistent results were reported for $\mathrm{PGF}_{2 \alpha}$ synthesis from these studies. Brazle et al. (2009), however, observed no effect on embryo number, development, or size on Day 11-19 of gestation in gilts but Rooke et al. (2001a) found that there was an increase in gestation length of sows.

To the best to our knowledge, no studies have been previously performed evaluating the effects of dietary PUFA $n-3$ supplementation on reproductive variables of rabbit female does. Therefore, the aim of the present study was to evaluate the influence of a long period of supplementation of rabbit female diets with PUFA $n-3$ at a moderate amount on (a) digestibility coefficients of diets, (b) pituitary-ovarian response, (c) FA profile of adipose tissues, and (d) performance variables of breeding does and viability of the litters during the first two production cycles.

\section{Materials and methods}

\subsection{Animals, housing and experimental diets}

A total of 125 New Zealand $\times$ California white rabbit does 11 weeks old weighing $2.4 \pm 0.17 \mathrm{~kg}$ (mean \pm SEM) were fed ad libitum two experimental diets from rearing to their second weaning. Animals were housed individually in flat-deck cages $(700 \mathrm{~mm} \times 500 \mathrm{~mm} \times 320 \mathrm{~mm})$ with a $16 \mathrm{~h}$ of light and $8 \mathrm{~h}$ of darkness light program. Temperature of the building was maintained between 18 and $23^{\circ} \mathrm{C}$ throughout the trial. All the experimental procedures used were approved by the Animal Ethics Committee of the Universidad Politécnica de Madrid, and were in compliance with the Spanish guidelines for care and use of animals in research (BOE, 2013).

Two isofibrous, isoenergetic, and isoproteic diets were formulated following the nutritional recommendations for breeding does issued by De Blas and Mateos (2010). Both diets had the same basal mixture of ingredients and only varied in the type of fat added: $7.5 \mathrm{~g} / \mathrm{kg}$ lard ( $n=63$ does) for the control diet (Diet C) and $15.0 \mathrm{~g} / \mathrm{kg}$ of a commercial supplement (Optomega-50; Optivite International Ltd., Spain) containing a $50 \%$ of ether extract and $35 \%$ of PUFA $n-3$ ( $n=62$ does) for the PUFA $n-3$ diet (Diet P). The ingredients and chemical composition of diets are provided in Table 1 , and the fatty acid profile of experimental diets in Table 2 .

\subsection{Digestibility trial, blood and adipose tissue sampling}

Twenty 16-week-old New Zealand $\times$ Californian doe rabbits (10 per diet) were used to collect feces, blood and adipose tissues. The digestibility assay was conducted with animals housed individually in conventional cages provided with a net covering of the floor that allowed for separation of feces and urine. After a 5-week period of experimental diet feeding, rabbits weighed $4.1 \pm 0.1 \mathrm{~kg}$ (mean \pm SEM), and feed intake and total fecal output were recorded for each animal over a 5-day period. Feces were collected daily and stored at $-20^{\circ} \mathrm{C}$ until drying at $-80^{\circ} \mathrm{C}$ for $48 \mathrm{~h}$, and were subsequently ground and passed through a $1 \mathrm{~mm}$ screen for chemical analyses.

Taking into account that FA profile of rabbit tissues can be effectively modified with 2-3 weeks of dietary supplementation (Szabó et al., 2001), at the end of a digestibility trial, all does were treated with $20 \mu$ g gonadorelin (Inducel$\mathrm{GnRH}$, Lab. Ovejero, León, Spain) to induce ovulation. Blood samples at 0 and $60 \mathrm{~min}$ as well as at 5, 7 and 9 days after induction of ovulation were taken from the marginal ear vein at 9:00 to 10:00 a.m. by collecting samples in tubes containing EDTA. Plasma was obtained after centrifugation at $1200 \times \mathrm{g}$ for $10 \mathrm{~min}$ at $4{ }^{\circ} \mathrm{C}$ and stored at $-20^{\circ} \mathrm{C}$ until analyzed. After the last sampling at Day 9 post-ovulation induction, all does were euthanized to determine ovulation rate and number of corpora lutea on the ovarian surface. Samples of periovarian, scapular and omental adipose tissues $(3-4 \mathrm{~g})$ were obtained at euthanasia moment and stored at $-20^{\circ} \mathrm{C}$ until analyzed. 
Table 1

Ingredient and chemical composition of control (C) and n-3 PUFA supplemented $(\mathrm{P})$ diets $(\mathrm{g} / \mathrm{kg}$, as fed basis unless otherwise indicated).

\begin{tabular}{|c|c|c|}
\hline & $\mathrm{C}$ & $\mathrm{P}$ \\
\hline \multicolumn{3}{|l|}{ Ingredient } \\
\hline Wheat bran & 300 & 300 \\
\hline Barley grain & 111 & 111 \\
\hline Sunflower meal $280 \mathrm{~g} / \mathrm{kg}$ CP & 199 & 199 \\
\hline Palmkernel $160 \mathrm{~g} / \mathrm{kg} \mathrm{CP}$ & 60.0 & 60.0 \\
\hline Lucerne meal & 100 & 100 \\
\hline Barley sprouts & 50.0 & 50.0 \\
\hline Sugarbeet pulp & 57.0 & 57.0 \\
\hline Sugarcane molasses & 30.0 & 30.0 \\
\hline Wheat straw & 42.0 & 42.0 \\
\hline Lard & 7.5 & - \\
\hline Sepiolite & 7.5 & - \\
\hline Optomega $50^{\mathrm{a}}$ & - & 15 \\
\hline Calcium carbonate & 19.0 & 19.0 \\
\hline Sodium chloride & 6.0 & 6.0 \\
\hline Lysine, $500 \mathrm{~g}$ & 1.7 & 1.7 \\
\hline Choline chloride & 0.3 & 0.3 \\
\hline Organic acids & 0.7 & 0.7 \\
\hline Min-vitpremix ${ }^{\mathrm{b}}$ & 3.0 & 3.0 \\
\hline Antioxidants ${ }^{\mathrm{c}}$ & 3.3 & 3.3 \\
\hline Zinc bacitracin premix ${ }^{\mathrm{d}}$ & 2.0 & 2.0 \\
\hline \multicolumn{3}{|l|}{ Chemical composition analyzed } \\
\hline Gross Energy, MJ/kg & 16.4 & 16.5 \\
\hline Dry matter & 906 & 904 \\
\hline Ash & 81.1 & 77.8 \\
\hline Crude protein & 16.0 & 16.0 \\
\hline Ether extract & 31.6 & 31.4 \\
\hline ANDFom & 332 & 335 \\
\hline ADFom & 161 & 163 \\
\hline ADL & 39.8 & 41.0 \\
\hline \multicolumn{3}{|c|}{ Chemical composition calculated } \\
\hline Lysine & 7.0 & 7.0 \\
\hline Methionine + Cystine & 2.6 & 2.6 \\
\hline Threonine & 5.5 & 5.5 \\
\hline Calcium & 12 & 12 \\
\hline Phosphorus & 5.6 & 5.6 \\
\hline
\end{tabular}

a Optivite International Ltd. (Spain); contained salmon fish oil, 100\%; ether extract, $50 \%$; $n-6,8 \% ; n-3,35 \%$; CP, $4 \%, \mathrm{ME}, 5254 \mathrm{kcal} / \mathrm{kg}$; and vitamin E, $2500 \mathrm{mg} / \mathrm{kg}$.

b Mineral and vitamin premix supplied per kg of complete diet: vitamin A 9999.9 IU; vitamin D 1080 IU; vitamin E, $200 \mathrm{mg} / \mathrm{kg}$; vitamin K3: $1.7 \mathrm{mg}$; Thiamine: $1.7 \mathrm{mg}$; Riboflavin: $4.3 \mathrm{mg}$; Pantothenic acid: $13.6 \mathrm{mg}$; Pyridoxine: $1.7 \mathrm{mg}$; Mn:22.7 mg; Co:595 $\mu \mathrm{g}$; Se: $140 \mu \mathrm{g} ; \mathrm{I}: 1.2 \mathrm{mg}$.

c Supplied per kg of diet: [E320 Butilhidroxianisol (BHA)+E324 Etoxiquina +E321 Butilhidroxitolueno (BHT) $30.000 \mathrm{mg}$; E562 sepiolite $910.000 \mathrm{mg}$ ] (Trow Nutrition Spain SA); Luctanox $3000 \mathrm{mg}$ (Lucta, Barcelona, Spain).

d Contained $100 \mathrm{mg}$ zinc-bacitracin/kg (APSA, Reus, Spain).

\subsection{Production trial}

The rest of does were randomly assigned to $\mathrm{C}$ and $\mathrm{P}$ dietary treatments, ( $n=52$ and $n=53$, respectively). The first artificial insemination (AI) was conducted at 16 week of age and the second AI at 11 days post-partum (dpp). At both inseminations, the same procedure was followed and data were recorded. Seminal doses with at least 20 million spermatozoa in $0.5 \mathrm{ml}$ of diluent (Magapor S.L., Zaragoza, Spain) were prepared using a pool of fresh heterospermic semen from a group of bucks selected for high growth performance. To induce ovulation, does were given an intra-muscular injection of $20 \mu$ g gonadorelin (InducelGnRH, Lab. Ovejero, León, Spain).
Table 2

Fatty acids composition ( $\mathrm{g} / \mathrm{kg}$ total fatty acid methyl esters) of control (C) and $n-3$ PUFA supplemented (P) diets.

\begin{tabular}{lcr}
\hline Diets & $\mathrm{C}$ & $\mathrm{P}$ \\
\hline Total SFA & 351.1 & 316.6 \\
C12:0 & 63.3 & 63.6 \\
C14:0 & 53.2 & 61.0 \\
C16:0 & 182.9 & 166.2 \\
C18:0 & 54.2 & 27.6 \\
Total MUFA & 267.4 & 205.9 \\
C16:1n-7 & 13.4 & 16.8 \\
C18:1n-9 & 240.9 & 177.0 \\
C20:1n-9 & 13.1 & 12.1 \\
Total PUFA & 380.9 & 477.2 \\
C18:2n-6 LA & 327.4 & 315.1 \\
C18:3n-3ALA & 40.8 & 44.5 \\
C18:4n-3 & 5.1 & 21.6 \\
C20:5n-3EPA & 0.0 & 33.9 \\
C22:5n-3DPA & 0.0 & 9.2 \\
C22:6n-3DHA & 0.0 & 40.0 \\
$n-9$ & 254.0 & 189.3 \\
$n-6$ & 335 & 328.0 \\
$n-3$ & 45.9 & 149.2 \\
$n-6 / n-3$ ratio & 7.29 & 2.20 \\
UI & 115 & 127 \\
\hline
\end{tabular}

SFA = Saturated fatty acids; MUFA= Monounsaturated fatty acids; PUFA = Polyunsaturated fatty acids. UI = Unsaturation index.

Fertility [(number of parturitions/number of AI) $\times 100]$, and duration of pregnancy (days) were determined. Females not pregnant after the first AI were excluded from the experiment. Does gave birth naturally and the date of birth was recorded. Total number of newborn, fetuses born alive and stillborn per litter was recorded and litters (total live born) were weighed. To more precisely determine the effect of PUFA on individual growth development of kits born alive, seven does per experimental group at first and at second parturition with $11.0 \pm 0.64$ live kits born alive and $1.81 \pm 0.33$ that were stillborn (mean \pm SEM) were sampled to determine individual kits body weight and size. Using a slide calliper, crown-rump (CRL; maximum distance from crown to tail basis) and head length (HL; from base of the skull to the tip of the nose), biparietal (BPD; from one parietal eminence to the other) and transversal thoracic diameter (TD) were measured. Litter size was subsequently standardized to 8-12 pups by removing or adding kits within each dietary treatment. Litter weight at 21 and 32 days (weaning), and average daily gain (ADG) of kits were measured. Milk production was estimated by weighing all the litters at 21 days of age and using the regression equation developed by De Blas et al. (1995), as follows: milk production $(\mathrm{kg})=0.75 \pm 1.75 \mathrm{LBW} 21(\mathrm{~kg})$; where LBW21 corresponds to live bodyweight of the litter at 21 days of lactation. Lactation mortality of kits was recorded and expressed as the percentage of rabbits dead at weaning with respect to the number of rabbits after standardizing litter size.

\subsection{Analytical methods}

\subsubsection{Diets and feces}

Chemical analysis of diets and feces were made following the AOAC official methods (2000) for dry matter (oven drying method: 934.01), ash (muffle furnace incineration: 
923.03), ether extract (solvent extraction: 920.39) and crude protein (Dumas method: 968.06; FP-528 LECO, St. Joseph, MI, USA) determinations. Gross energy was determined by combustion in an adiabatic calorimetric pump (model 1356, Parr Instrument Company, Moline, IL, USA). Neutral detergent fiber (NDF) of feces and diets, and acid detergent fiber (ADF) and acid detergent lignin (ADL) of diets were determined using a filter bag system (Ankom Technology, New York, NY, USA) and following the procedures of Mertens (2002) for aNDFom and the AOAC official method 973.18 for ADFom and ADL (AOAC, 2000).

\subsubsection{Fatty Acid profile}

Fatty acid profiles from adipose tissue samples were extracted using a mixture of chloroform/methanol (2:1, $\mathrm{v} / \mathrm{v})$, methylated in the presence of sodium methoxide and quantified as previously described (Cordero et al., 2011). A Hewlett Packard HP-5890 (Avondale, PA, USA) gas chromatograph equipped with a flame ionization detector was used (capillary column HP-Innowax, $30 \mathrm{~m} \times 0.32 \mathrm{~mm}$ id and $0.25 \mu \mathrm{m}$ film thickness) (Agilent Technologies Gmbh, Germany). A split ratio of 50:1 was used and C15:0 was included as internal standard. Fatty acid profiles from diets were analyzed acording to Sukhija and Palmquist (1988) and the identification and quantification were made by chromatography according to conditions previously described.

\subsubsection{Hormones}

Plasma LH concentrations were determined by a homologous ELISA method validated for rabbits and described by Rebollar et al. (2012). Briefly, the RbLH antigen was biotinylated with EZ-Link ${ }^{\circledR}$ Biotinylation Kit according to the manufacturer's instructions. EIA microtiter plates were coated with secondary antibody anti-guinea pig IgG. Then, the anti RbLH were added into wells. Duplicates of $50 \mu \mathrm{l}$ of appropriate standards (range $0.781-400 \mathrm{ng} / \mathrm{ml}$ ), buffer (zero standard), plasma samples and assay controls were pipetted into respective wells. Biotinylated-RbLH (EZ-Link ${ }^{\circledR}$ Biotinylation Kit), Streptavidin-peroxidase) and the substrate $\left(3,3^{\prime}, 5,5^{\prime}\right.$-tetramethylbenzidine $)$ were added across the entire plate. The lowest concentration of RbLH that could be distinguished from zero concentration was $0.78 \mathrm{ng} / \mathrm{ml}$. The intra-assay coefficient of variation of the analysis was $5.2 \%$. Inter-assay precision calculated by the nine replicate measurements of coefficient of variation for pools of high and low concentrations was 3.1 and 6.84, respectively. The accuracy of the EIA, determined by measuring the recovery rates of known amounts of RbLH (5, 25 , and $125 \mathrm{ng} / \mathrm{ml}$ ) added to different plasma samples, was $90.0 \%, 96.0 \%$, and $88.6 \%$ for low, medium and high values, respectively.

Plasma progesterone concentrations were analyzed using a commercial kit (Progesterone ELISA, Demeditec Diagnostics $\mathrm{GmbH}$, Germany) based on the principle of competitive binding. Previously, plasma samples were extracted with petroleum ether at a 5:1(v/v) ether:sample ratio (Extraction efficiency was 85\%). Sensitivity was $0.045 \mathrm{ng} / \mathrm{ml}$. The intra- and inter-assay coefficients of variation were $5.5 \%$ and $6.9 \%$, respectively.
Absorbance was measured in a Bio-Tek automatic plate reader (Epoch $^{\mathrm{TM}}$ Microplate Spectrophotometer, Bio-Tek Instruments, Winooski, Vermont, USA) at 450 and $630 \mathrm{~nm}$, and hormone concentrations calculated by means of a software developed for these techniques (Gen5 ${ }^{\mathrm{TM}}$ ELISA, Bio-Tek Instruments).

\subsection{Statistical analysis}

Statistical analysis was performed with Statistical Analysis System software (SAS, 1990). The daily feed intake and apparent digestibility coefficients were analyzed as a completely randomized design with feeding regime as the main source of variation by using the GLM procedure as well as fatty acid profile in adipose tissue but considering the diet, the type of adipose tissue (ovarian, scapular and abdominal) and the interaction as main factors. The effect of dietary supplementation on ovulation and fertility rates was analyzed by means a $\chi^{2}$ test (proc CATMOD). Plasma concentrations of $\mathrm{LH}$ and progesterone were studied by repeated measure analysis using the MIXED procedure with feeding regimen, time and the interaction as main effects. Production performance data (duration of pregnancy, prolificacy, litter size and litter weight at birth and at 21 and 32 days of age, mortality during the lactation period, estimated milk production, and ADG) were analyzed by repeated measure analysis using the MIXED procedure considering the diet, the AI order (16 weeks of age and 11 $\mathrm{dpp}$ ) and the interaction. Doe was considered a random effect nested in the treatment. Mortality of kits during lactation was analyzed using the litter as the experimental unit. To study the effect of diet, order of AI and the interaction on kits body weight and size, a GLM procedure was used considering the number of total kits born per litter as covariable. All means were compared using a protected $t$ test, and differences were considered significant at $P<0.05$ and a trend when $P<0.10$. Results are presented as leastsquared mean (lsmeans).

\section{Results}

\subsection{Digestibility trial}

Dietary treatments did not affect either daily feed intake, apparent digestibility coefficients of dry matter, NDF, crude protein, ether extract and digestible energy content of diets with averages being $200 \pm 7.11 \mathrm{~g} / \mathrm{d}$, $60.7 \pm 0.53 \%, 30.3 \pm 0.60 \%, 65.2 \pm 1.01 \%, 76.4 \pm 1.41 \%$ and $10.04 \pm 0.12 \mathrm{MJ} / \mathrm{kg}$, respectively.

\subsection{Pituitary and ovarian response}

No significant differences were observed in ovulation rate (100\% and $90.9 \%)$ and number of corpora lutea per doe $(9.6 \pm 0.9$ and $10.1 \pm 1.0)$ for the $P$ and $C$ groups, respectively. Sixty minutes after ovulation induction an increase of LH (Fig. $1 ; P<0.0001$ ) was observed in does from both groups and there was a decrease to basal concentrations afterwards. At $60 \mathrm{~min}$ after ovulation induction, does supplemented with PUFA $n-3$ had greater plasma LH 


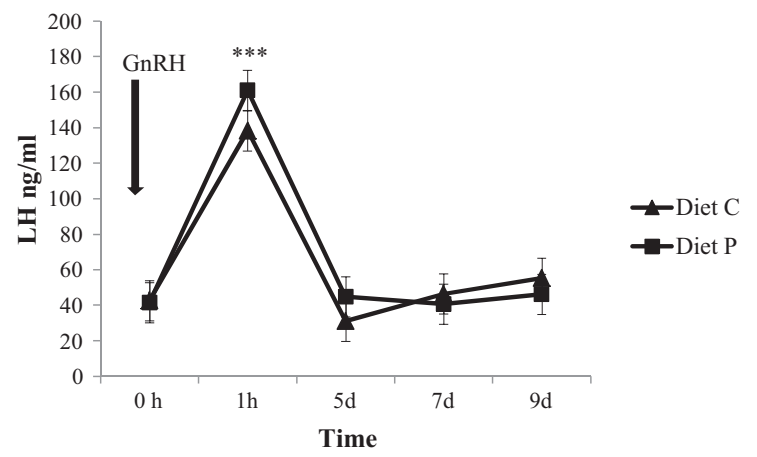

Fig. 1. Plasma LH concentrations after induction of ovulation in rabbit does fed a Control (C) and a PUFA $n-3$ supplemented diet $(P)$ at 0 and $1 \mathrm{~h}$ (h) and 5, 7 and 9 days (d), respectively. All values are lsmeans $(n=10)$; *** Time effect at $1 \mathrm{~h}(P=0.0001)$; Diet $\times$ Time interaction at $1 \mathrm{~h}(P=0.14)$.

concentrations than those of the control group (diet $\times$ time interaction; $P=0.14$ ).

Plasma progesterone concentrations from does increased at $60 \mathrm{~min}$ (Fig. $2 ; P<0.05)$ and 5 days $(P<0.05)$ after induction of ovulation and remained high on Day 7 and 9 in both experimental groups. Rabbit does fed Diet $P$ tended to have greater progesterone concentrations than those fed Diet $C$ on Days $5(P=0.068)$ and $7(P=0.082)$ after induction of ovulation.

\subsection{Fatty acid profile in adipose tissues}

Differences in fatty acid profile of the three types of adipose tissues from rabbit does fed dietary treatments are shown in Table 3. Diets supplemented with PUFA $n$ 3 resulted in a lesser $(P<0.001)$ MUFA and greater SFA and PUFA contents in adipose tissues. An increase of dietary PUFA $n-3$ supplementation from 0.14 to $4.69 \mathrm{~g} / \mathrm{kg}$ of diet increased adipose tissue concentrations of EPA $(P<0.05)$,

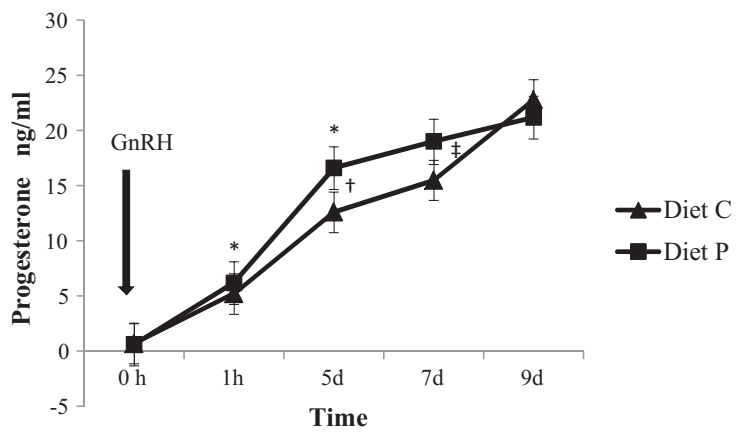

Fig. 2. Plasma progesterone concentrations after induction of ovulation in rabbit does fed a Control (C) and a PUFA $n$ - 3 supplemented diet (P) at 0 and $1 \mathrm{~h}(\mathrm{~h})$ and 5,7 and 9 days (d), respectively. All values are lsmeans $(n=10)$; ${ }^{*}$ Time effect at $1 \mathrm{~h}(P<0.05)$ and 5 days $(\mathrm{d})(P<0.05)$; Diet $\times$ Time interaction at $5 \mathrm{~d}(\dagger: P=0.068)$ and $7 \mathrm{~d}(\ddagger: P=0.082)$.

total PUFA $n-3(P<0.01)$ and $n-6(P<0.001)$ by $9.0 \%, 6.7 \%$, and $9.2 \%$, respectively, but did not influence DHA or AA content. The ratio between total $n-6$ to total $n-3$ contents in adipose tissues was similar ( $10.5 \mathrm{~g} / \mathrm{kg}$, as average) between dietary treatments. Fatty acid profile differed among the three types of adipose tissues analyzed in both groups. A greater concentration of EPA $(P<0.05)$, DPA and DHA $(P<0.001)$ was observed for periovarian than scapular fat with abdominal fat being intermediate. The greatest concentration of SFA was found in scapular fat.

\subsection{Production trial}

The dietary supplementation with PUFA $n-3$ did not affect any production variable of rabbit does studied (Table 4$)$. Fertility rate was less $(P=0.0001)$ but pregnancy duration $(P=0.0001)$, litter weight at parturition $(P=0.0001)$ and at weaning $(P=0.0001)$ were greater after

Table 3

Fatty acids profile ( $\mathrm{g} / \mathrm{kg}$ total fatty acid methyl esters) of adipose tissue of rabbit does fed Control (C) and PUFA $n$-3 supplemented (P) diets.

\begin{tabular}{|c|c|c|c|c|c|c|c|c|}
\hline \multirow[t]{2}{*}{$N$} & \multicolumn{2}{|l|}{ Diet } & \multicolumn{3}{|c|}{ Adipose tissue (AT) } & \multirow[b]{2}{*}{ SD } & \multicolumn{2}{|l|}{$\mathrm{P}>\mathrm{F}$} \\
\hline & $\begin{array}{l}C \\
10\end{array}$ & $\begin{array}{l}P \\
10\end{array}$ & $\begin{array}{l}\text { Periovarian } \\
20\end{array}$ & $\begin{array}{l}\text { Scapular } \\
20\end{array}$ & $\begin{array}{l}\text { Abdominal } \\
20\end{array}$ & & Diet & AT \\
\hline \multicolumn{9}{|l|}{ Fatty acids } \\
\hline $\mathrm{C} 14: 0$ & 36.2 & 39.7 & $35.9^{a}$ & $39.7^{\mathrm{b}}$ & $38.2^{\mathrm{b}}$ & 2.9 & 0.0001 & 0.0009 \\
\hline C16:0 & 269 & 279 & $268^{a}$ & $280^{\mathrm{b}}$ & $274^{\mathrm{ab}}$ & 10.0 & 0.0001 & 0.0016 \\
\hline C16:1 n-9 & 87.9 & 78.0 & $93.2^{\mathrm{a}}$ & $70.9^{\mathrm{b}}$ & $84.7^{\mathrm{a}}$ & 14.3 & 0.0116 & 0.0001 \\
\hline C18:0 & 59.1 & 60.5 & $59.7^{\mathrm{a}}$ & $66.1^{\mathrm{b}}$ & $53.5^{c}$ & 8.49 & 0.5359 & 0.0001 \\
\hline C18:1 n-9 & 292 & 271 & $277^{\mathrm{b}}$ & $285^{\mathrm{a}}$ & $282^{\mathrm{a}}$ & 11.7 & 0.0001 & 0.1108 \\
\hline C18:1 n-7 & 176 & 153 & 16.8 & 16.4 & 16.1 & 2.84 & 0.0041 & 0.7306 \\
\hline C18:2 n-6 LA & 178 & 194 & 187 & 182 & 190 & 15.4 & 0.0002 & 0.3059 \\
\hline C18:3 n-3 ALA & 16.3 & 17.2 & 16.7 & 16.7 & 17.0 & 1.27 & 0.0083 & 0.7560 \\
\hline$C 18: 4 n-3$ & 0.60 & 0.53 & 0.58 & 0.54 & 0.53 & 1.57 & 0.2614 & 0.5953 \\
\hline C20:4 n-6 ARA & 1.50 & 1.60 & 1.49 & 1.62 & 1.53 & 2.40 & 0.1156 & 0.2349 \\
\hline C20:5 n-3 EPA & 0.21 & 0.23 & $0.23^{a}$ & $0.20^{\mathrm{b}}$ & $0.23^{a}$ & 0.04 & 0.0289 & 0.0377 \\
\hline C22:5 n-3 DPA & 0.62 & 0.72 & $0.92^{\mathrm{a}}$ & $0.41^{\mathrm{c}}$ & $0.68^{\mathrm{b}}$ & 0.2 & 0.0546 & 0.0001 \\
\hline C22:6n-3 DHA & 0.76 & 0.88 & $1.03^{\mathrm{a}}$ & $0.66^{\mathrm{b}}$ & $0.77^{\mathrm{b}}$ & 0.3 & 0.1123 & 0.0006 \\
\hline$n-6$ & 184 & 201 & 193 & 189 & 196 & 19.0 & 0.0002 & 0.3618 \\
\hline$n-3$ & 17.9 & 19.1 & 18.9 & 17.9 & 18.6 & 1.40 & 0.0025 & 0.1208 \\
\hline$n-6 / n-3$ & 10.3 & 10.6 & 10.2 & 10.5 & 10.5 & 0.71 & 0.1702 & 0.3817 \\
\hline Total SFA & 380 & 394 & $378^{a}$ & $401^{\mathrm{b}}$ & $381^{\mathrm{a}}$ & 13.9 & 0.0001 & 0.0001 \\
\hline Total MUFA & 418 & 385 & $409^{a}$ & $391^{b}$ & $404^{\mathrm{a}}$ & 19.0 & 0.0001 & 0.0152 \\
\hline Total PUFA & 202 & 220 & 213 & 207 & 215 & 16.7 & 0.0002 & 0.3288 \\
\hline
\end{tabular}

Differences are indicated with different letters on the same row; SD=Standard deviation; $n=$ No. of does; Interaction (Diet $\times$ AT) was not significant; SFA = Saturated fatty acids; MUFA = Monounsaturated fatty acids; PUFA = Polyunsaturated fatty acids. 
Table 4

Production variables of rabbit does fed a Control (C) or a PUFA $n-3$ supplemented (P) diets artificially inseminated (AI) either at16 weeks of age (1) or at 11 days post-partum (dpp; 2).

\begin{tabular}{|c|c|c|c|c|c|c|c|c|}
\hline & \multicolumn{2}{|l|}{ Diet } & \multicolumn{2}{|l|}{ AI order } & \multirow[b]{2}{*}{ SE } & \multicolumn{3}{|l|}{$\mathrm{P}>\mathrm{F}$} \\
\hline & C & $\mathrm{P}$ & 1 & 2 & & Diet & AI & Diet $\times$ AI \\
\hline No. of does & 97 & 96 & 105 & 88 & & & & \\
\hline Fertility (\%) & 71.7 & 64.9 & 83.6 & 52.9 & 5.52 & 0.3135 & 0.0001 & 0.4707 \\
\hline Pregnancy (days) & 30.9 & 31.0 & 30.8 & 31.2 & 0.07 & 0.3246 & 0.0001 & 0.5897 \\
\hline Parturitions & 65 & 65 & 88 & 42 & & & & \\
\hline Born alive & 10.1 & 9.85 & 9.94 & 10.0 & 0.47 & 0.6495 & 0.8856 & 0.8130 \\
\hline Stillborn & 0.60 & 0.25 & 0.16 & 0.64 & 0.20 & 0.2475 & 0.0831 & 0.0709 \\
\hline Weaned (32 dpp) & 9.3 & 8.9 & 9.2 & 9.1 & 0.32 & 0.3109 & 0.7757 & 0.5084 \\
\hline \multicolumn{9}{|l|}{ Litter weight } \\
\hline Birth (g) & 576 & 564 & 491 & 650 & 17.1 & 0.6448 & 0.0001 & 0.4722 \\
\hline Weaning (32 dpp) (g) & 6075 & 5974 & 5649 & 6400 & 172 & 0.6548 & 0.0001 & 0.7617 \\
\hline Milk production (g) & 6992 & 7124 & 5965 & 8151 & 168 & 0.5506 & 0.0001 & 0.2475 \\
\hline \multicolumn{9}{|l|}{ Lactation } \\
\hline Mortality (\%) & 4.85 & 4.54 & 3.66 & 5.72 & 1.75 & 0.8898 & 0.2564 & 0.1437 \\
\hline $\mathrm{ADG}(\mathrm{g} / \mathrm{d})$ & 19.0 & 19.6 & 17.9 & 20.7 & 0.79 & 0.3609 & 0.0001 & 0.2043 \\
\hline
\end{tabular}

All values are lsmeans. ADG = Average Daily Gain.

the second compared to the first AI. Number of stillborn kits tended to be greater at the second parturition $(P=0.08)$. Milk production and ADG were greater $(P=0.0001)$ in the second lactation but kit mortality was similar in both production cycles.

There was a significant interaction on kit mortality at parturition between dietary treatments and parturition order (Fig. 3). Control does at second parturition had an increase of stillborn kits as compared with the first parturition $(P<0.0103)$, while PUFA $n-3$ supplemented does had a similar kit mortality at the first and second parturition. Moreover, when a representative sample of litters was studied belonging to two experimental groups, kits born to PUFA $n-3$ supplemented does tended to be heavier than kits born to control does $(50.6 \pm 2.92$ compared with $42.7 \pm 3.07 \mathrm{~g}$, respectively; $P=0.0761$ ) independent of the order of parturition. Both, the diet and order of parturition affected CRL being greater in kits born to PUFA supplemented than control does $(8.19 \pm 0.17$ compared with $7.70 \pm 0.18 \mathrm{~cm} ; P=0.0598)$ and at second than at first parturition $(8.39 \pm 0.19$ compared with $7.5 \pm 0.16 \mathrm{~cm} ; P=0.018)$.

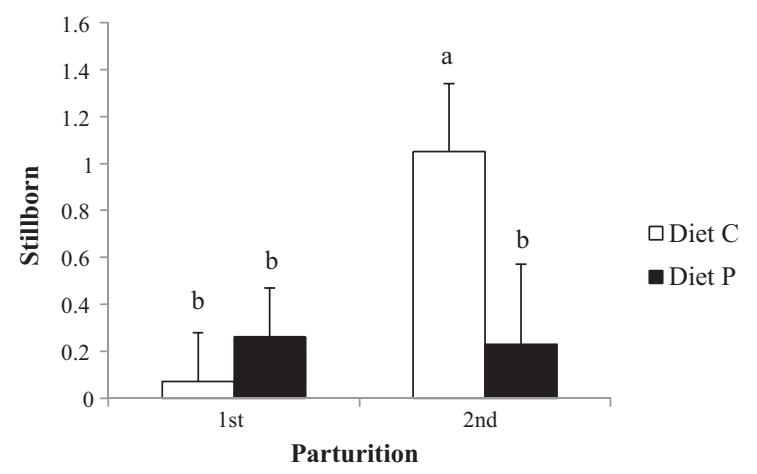

Fig. 3. Number of stillborn kits per litter born to rabbit does fed a Control (C) or a $n-3$ PUFA supplemented diet (P), at first and second parturition; Each bar represents the lsmeans from 44, 43, 23 and 18 parturitions from left to right; Diet $\times$ Parturition $(a, b: P<0.05)$.
Thoracic diameter and HL were also greater at the second parturition than at the first parturition $(2.18 \pm 0.05$ compared with $1.84 \pm 0.05 \mathrm{~cm}$ and $2.9 \pm 0.10$ compared with $2.56 \pm 0.11 \mathrm{~cm} ; P=0.0001$ and $P=0.0286)$. BPD was not affected by diet or by parturition order.

\section{Discussion}

The digestibility of nutrients was not affected by the dietary PUFA $n-3$ supplementation. These results were expected because of the moderate amounts of dietary fat supplementation used in the present study (15 g/kg). Fernández et al. (1994) and Casado et al. (2010) using a greater amount $(30 \mathrm{~g} / \mathrm{kg})$ of supplementation with different fat sources varying in the ratios of saturated/unsaturated FA did not observe any difference on nutrient digestibility in fattening rabbits. Nevertheless, Dalle Zotte et al. (2013) observed a slight decrease of the apparent digestibility coefficient of ether extract in 11-week-old rabbits due to the increase of PUFA content $(20 \mathrm{~g} / \mathrm{kg})$ in diets supplemented with Spirulina meal.

Even though estradiol concentration was not determined because rabbit does, as an induced ovulation species, does not have estradiol-induced pre-ovulatory LH surges (Bakker and Baum, 2000), the tendency for an increase in LH at 30 min after ovulation induction in PUFA $n-3$ supplemented does could imply greater ovarian follicular development and steroid production as a result of ovulation induction. Nonetheless, to ascertain if PUFA $n-3$ supplementation could lead a mechanistic action on steroidogenesis, both $\mathrm{LH}$ and progesterone were determined before and after ovulation induction. Studies conducted in vitro (Mattos et al., 2003) and in vivo in beef heifers (Coyne et al., 2008) indicated that PUFA $n-3$ supplementation can alter endometrial expression of genes regulating $\mathrm{PGF}_{2} \alpha$ synthesis, possibly leading to a reduction in uterine $\mathrm{PGF}_{2} \alpha$ production. Inhibition of uterine $\mathrm{PGF}_{2} \alpha$ secretion may inhibit or delay the regression of the 
CL, improving pre-implantation embryo survival. However, recently Hutchinson et al. (2012) have observed that a short period of $n-3$ PUFA supplementation ( 5 days) to dairy cows (previously submitted to hormonal estrous synchronization) did not suppress the expression of genes encoding for enzymes involved in $\mathrm{PGF}_{2} \alpha$ synthesis and compared to other fat sources (CLA or flax seed), $n-3$ supplemented cows had reduced progesterone concentrations and corpora lutea volumes, thus, these findings do not support the hypothesis of Coyne et al. (2008). MacLaren et al. (2006), however, suggested that the possible beneficial effects of PUFA $n-3$ on progesterone production could be due to activation of the nuclear family of peroxisome proliferatoractivated receptors (PPAR) in luteinized cells. In particular, PPAR $\gamma$ could be responsible for preserving corpus luteum function to support implantation and pregnancy in various species (for review, see Froment et al., 2006). In rabbit does, Zerani et al. (2013) have demonstrated a luteotropic role of PPAR $\gamma$ in corpora lutea cultured in vitro at an early stage (Day 4 post-ovulation) providing a possible explanation for the moderate increase of plasma progesterone observed in $n$-3 PUFA supplemented does in the present study.

The FA profile of the experimental diet not only was effectively modified after 5 weeks of dietary supplementation with $n$-3 PUFA the FA deposition was different depending on the type of adipose tissue analyzed. The greater concentration of $n-3$ PUFA in periovarian adipose tissue of supplemented does could indicate the manifestation of a favorable reservoir of $n-3$ essential PUFA next to the ovarian vessels and cells, available to be incorporated in metabolic and physiologic ovarian processes... This finding could also explain the tendency of luteal progesterone concentrations to be greater in treated animals in the present study.

During pregnancy and the first days of lactation both the developing fetus and offspring are totally dependent on the mother for nutritional requirements, growth, development and pregnancy outcome. In accordance to the similar basal chemical composition and digestible energy content of the two diets, there was no n-3 PUFA supplementation effect on litter size and weight at birth and at weaning as well as on milk production and ADG in the present study.

It appears as though the transfer of FA from the mother depends on timing, duration, and amount of supplementation as well as type of FA supplemented in maternal diets. Consistent with this, $1 \%$ salmon oil fed from Day 60 of pregnancy in sows was the optimal amount to achieve the greatest relative brain weight of piglets (Rooke et al., 2001b), and the late gestation period would be the period when there is FA from tuna oil that is transferred to the placenta (Rooke et al., 2001c). In the present study, a moderate PUFA $n-3$ supplementation occurred continuously from rearing to second weaning leading to changes on the FA composition of mother's adipose tissues from the beginning of reproductive life. Considering this prolonged supplementation and taking into account the discoidal hemochorial structure of the rabbit placenta that optimizes feto-maternal exchanges compared to other species (Fischer et al., 2012), the PUFA supplementation could explain the favorable long-term effect on reducing the number of stillborn kits after the second parturition, as well as on increasing the weight and size of live born kits from a representative number of litters sampled from the production trial.

Problems related to greater lipid oxidation, less feed intake because of lesser palatability and reduced growth rates have been observed in previous studies using fish oil in rabbit diets (Navarrete et al., 2007; Bernardini et al., 1999; Al-Nouri et al., 2012). For this reason, a moderate inclusion of dietary PUFA supplementation was chosen from the present experimental diets. However, taking into account the results, some long-term positive effects were observed in the production trial and the use of greater amounts of dietary PUFA $n-3$ supplementation should be studied for further elucidation of positive effects of PUFA $n-3$ supplementation.

In conclusion, feeding PUFA is a "two-edged sword" (some are essential, but too many are potentially harmful) as Whates et al. (2007) indicated. Both stimulatory and inhibitory effects and responses of animals have resulted in previous studies. In the present study, long-term dietary supplementation of $15 \mathrm{~g} / \mathrm{kg}$ of a supplement that contained $50 \%$ ether extract and more than 30\% unsaturated fatty acids as a fat source: (1) did not affect nutrient digestibility, (2) n-3 PUFA concentrations were greatly reflected in periovarian adipose tissue, (3) tended to improve endocrine function of corpora lutea around the implantation period, and 4 ) tended to increase weight and size of kits, and reduced mortality at second parturition while not affecting other production variables.

\section{Acknowledgments}

This research was supported by project AGL2011-23822 and S2009/AGR-1704 funding from the Spanish Ministry of Science and Technology and the Community of Madrid respectively. The authors wish to thank Marco M., Pascual J.I., Velasco B. and Astillero J.R. for their invaluable support in the experimental part of this work.

\section{References}

Al-Nouri, D.M., Al-Khalifa, A.S., Shahidi, F., 2012. Long-term supplementation of dietary omega-6/omega-3 ratios alters bone marrow fatty acid and biomarkers of bone metabolism in growing rabbits. J. Functional Foods 4, 584-593.

Association of Official Analytical Chemists International, 2000. Official Methods of Analysis of the AOAC International, 17th ed. AOAC International, Galthersburg, MD, USA.

Bakker, J., Baum, M.J., 2000. Neuroendocrine regulation of GnRH release in induced ovulators. Front. Neuroendocrinol. 21, 220-262.

Benatmane, F., Kouba, M., Youyou, A., Mourot, J., 2011. Effect of a linseed diet on lipogenesis, fatty acid composition and stearoyl-CoAdesaturase in rabbits. Animal 5, 1993-2000.

Bernardini, M., Dal Bosco, A., Castellini, C., 1999. Effect of dietary n-3/n6 ratio on fatty acid composition of liver, meat and perirrenal fat in rabbit. Anim Sci. 68, 647-654

Boletín Oficial del Estado, 2013. Real Decreto 53/2013, por el que se establecen las normas básicas aplicables para la protección de los animales utilizados en experimentación y otros fines científicos, incluyendo la docencia. B.O.E. 34, 11370-11421.

Brazle, A.E., Johnson, B.J., Webel, S.K., Rathbun, T.J., Davis, D.L., 2009. Omega-3 fatty acids in the gravid pig uterus as affected by maternal supplementation with omega-3 fatty acids. J. Anim. Sci. 87, 994-1002.

Casado, C., Moya, V.J., Fernández, C., Pascual, J.J., Blas, E., Cervera, C., 2010. Diet digestibility in growing rabbits: effect of origin and oxidation level of dietary fat and vitamina E supplementation. World Rabbit Sci. 18, 57-63. 
Cordero, G., Isabel, B., Morales, J., Menoyo, D., Piñeiro, C., López-Bote, C.J., 2011. Effect of dietary CLA administration on fatty acid composition and lipogenic and lipolytic enzyme activities in suckling and weaned piglets. Anim. Feed Sci. Technol. 164, 232-240.

Coyne, G.S., Kenny, D.A., Childs, S., Sreenan, J.M., Waters, S.M., 2008. Dietary n-3 polyunsaturated fatty acids alter the expression of genes involved in prostaglandin biosynthesis in the bovine uterus. Theriogenology 70 (772-282).

Dal Bosco, A., Mourvaki, E., Cardinali, R., Servili, M., Sebastiani, B., Ruggeri, S., Mattioli, S., Taticchi, A., Esposto, S., Castellini, C., 2012. Effect of dietary supplementation with olive pomaces on the performance and meat quality of growing rabbits. Meat Sci. 92, 783-788.

Dalle Zotte, A., Sartori, A., Bohatir, P., Rémignon, H., Ricci, R., 2013. Effect of dietary supplementation of spirulina (Arthrospira platensis) and Thyme (Thymus vulgaris) on growth performance, apparent digestibility and health status of companion dwarf rabbits. Livestock Sci. 152, 182-191.

De Blas, C., Mateos, G.G., 2010. Feed formulation. In: de Blas, C., Wiseman, J. (Eds.), The Nutrition of the Rabbit., 2nd ed. CABI Publishing CAB International, Wallingford, UK, pp. 222-232.

Fernández, C., Cobos, A., Fraga, M.J., 1994. The effect of fat inclusion on diet digestibility in growing rabbits. J. Anim. Sci. 72, 1508-1515.

Fischer, B., Chavett-Palmer, P., Viebahn, C., Navarrete Santos, A., Duranthon, V., 2012. Rabbit as a reproductive model for human health. Reproduction 144, 1-10.

Froment, P., Gizard, F., Defever, D., Staels, B., Dupont, J., Monget, P., 2006. Peroxisome proliferator-activated receptors in reproductive tissues: from gametogenesis to parturition. J. Endocrinol. 189, 199-209.

Harris, W.S., 2007. International recommendations for consumption of long-chain omega-3 fatty acids. J. Cardiovasc. Med. 8, 50-52.

Hernández, P., Pla, M., Oliver, M.A., Blasco, A., 2000. Relationships between meat quality measurements in rabbits fed with three different fat type and content. Meat Sci. 55, 379-384.

Hinckley Sr., T., Clark, R.M., Bushmich, S.L., Milvae, R.A., 1996. Long chain polyunsaturated fatty acids and bovine luteal cell function. Biol. Reprod. 55, 445-449.

Hutchinson, I.A., Hennessy, A.A., Waters, S.M., Dewhurst, R.J., Evans, A.C.O., Lonergan, P., Butler, S.T., 2012. Effect of supplementation with different fat sources on the mechanisms involved in reproductive performance in lactating dairy cattle. Theriogenology 78, 12-27.

MacLaren, L.A., Guzeloglu, A., Michel, F., Thatcher, W.W., 2006. Peroxisome proliferator-activated receptor (PPAR) expression in cultured bovine endometrial cells and response to omega-3 fatty acid, growth hormone and agonist stimulation in relation to series 2 prostaglandin production. Domest. Anim. Endocrinol. 30, 155-169.

Mattos, R., Guzeloglu, A., Badinga, L., Staples, C.R., Thatcher, W.W., 2003. Polyunsaturated fatty acids and bovine interferon-tau modify phorbol ester-induced secretion of prostaglandin F2 alpha and expression of prostaglandin endoperoxide synthase- 2 and phospholipase-A2 in bovine endometrial cells. Biol. Reprod. 69, 780-787.

Mattos, R., Staples, C.R., Arteche, A., Wiltban, k, M.C., Diaz, F.J., Jenkins, T.C., Thatcher, W.W., 2004. The effects of feeding fish oil on uterine secretion of PGF (2alpha), milk composition, and metabolic status of periparturient Holstein cows. J. Dairy Sci. 87, 921-932.

Mertens, D.R., 2002. Gravimetric determination of amylase-treated neutral detergent fibre in feeds with refluxing beakers or crucibles: collaborative study. J. Assoc. Off. Ann. Chem. 85, 1217-1240.

Navarrete, C., Martínez, E., Ródenas, I., Moya, V.J., Pascual, J.J., Blas, E., Cervera, C., 2007. Empleo de destilados de palma y de aceites de pescado en piensos de conejos. II Congreso Ibérico de Cunicultura. Vila Real Trás os Montes Portugal., 5 y 6 de junio, 73-76.
Needleman, P., Turk, J., Kakshik, B.A., Morrison, A.R., Lefkowith, J.B., 1986. Arachidonic acid metabolism. Ann. Rev. Biochem. 55, 69-102.

Peiretti, P.G.,2012. Effects of dietary fatty acids on lipid traits in the muscle and perirenal fat of growing rabbits fed mixed diets. Animal 2, 55-67.

Rebollar, P.G., Dal Bosco, A., Millán, P., Cardinali, R., Brecchia, G., Sylla, L., Lorenzo, P.L., Castellini, C., 2012. Ovulating induction methods in rabbit does: the pituitary and ovarian responses. Theriogenology 77, 292-298.

Rooke, J.A., Sinclair, A.G., Edwards, S.A., Cordoba, R., Pkyyach, S., Penny, P.C., Penny, P., Finch, A.M., Horgan, G.W., 2001a. The effect of feeding salmon to sow throughout pregnancy on pre-weaning mortality of piglets. Animal Sci. 73, 489-500.

Rooke, J.A., Sinclair, A.G., Ewen, M., 2001b. Changes in piglet tissues composition at birth in response to increasing maternal intake of longchain $n-3$ polyunsaturated fatty acid are non-linear. Br. J. Nutr. 86, $461-470$.

Rooke, J.A., Sinclair, A.G., Edwards, S.A., 2001c. Feeding tuna oil to the sow at different times during pregnancy has different effects on piglet long-chain polyunsaturated fatty acid composition at birth and subsequent growth. Br. J. Nutr. 86, 21-30.

Santos, J.E., Bilby, T.R., Thatcher, W.W., Staples, C.R., Silvestre, F.T., 2008. Long chain fatty acids of diet as factors influencing reproduction in cattle. Reprod. Domest. Anim. 43, 23-30.

SAS Institute, 1990. SAS/STAT ${ }^{\circledR}$ User’s Guide (Release 8.2). SAS Inst. Inc., Cary NC, USA.

Staples, C.R., Burke, J.M., Thaycher, W.W., 1998. Influence of supplemental fats on reproductive tissues and performance of lactating cows. J. Dairy Sci. 81, 856-871.

Sukhija, P.S., Palmquist, D.L., 1988. Rapid method for determination of total fatty acid content and composition of feedstuffs and feces. J. Agric. Food Chem. 36, 1202-1206.

Szabó, A., Romvári, R., Fébel, H., Nagy, I., Szandr, Z.S., 2001. Fatty acid composition of two different muscles in rabbits: alterations in response to saturated or unsaturated fatty acid complementation. World Rabbit Sci. 9, 155-158.

Tres, A., Bou, R., Codony, R., Guardiola, F., 2008. Influence of different dietary doses of $n-3$ or $n-6$ rich vegetable fats and alpha-tocopheryl acetate supplementation on raw and cooked rabbit meat composition and oxidative stability. J. Agric. Food Chem. 56, 7243-7253.

Tres, A., Bou, R., Codony, R., Guardiola, F., 2009. Dietary n-6 or n-3 rich vegetable fats and alpha-tocopheryl acetate: effects on fatty acid composition and stability of rabbit plasma, liver and meat. Animal 3, $1408-1419$.

Trujillo, E.P., Beoughton, Ks., 1995. Ingestion of n-3 polyunsaturated fatty acids and ovulation in rats. J. Reprod. Fert. 105, 197-203.

Wang, X.J., Dyson, M.T., Jo, Y., Eubank, D.W., Stocco, D.M., 2003. Involvement of 5-lipoxygenase metabolites of arachidonic in cyclic AMP-stimulated steroidogenesis and steroidogenic acute regulatory protein gene expression. J. Steroid Biochem. Mol. Biol. 85, 159-166.

Wathes, D.C., Abayasekara, D.R.E., Aitken, R.J., 2007. Polyunsaturated fatty acids in male and female reproduction. Biol. Reprod. 77, 190-201.

Zerani, M., Maranesi, M., Brecchia, G., Gobbetti, A., Boiti, C., Parillo, F., 2013. Evidence for a luteotropic role of peroxisome proliferator-activated receptor gamma: expression and in vitro effects on enzymatic and hormonal activities in corpora lutea of pseudopregnant rabbits. Biol. Reprod. 88, 437-450.

Zeron, Y., Sklan, D., Arav, A., 2002. Effect of polyunsaturated fatty acid supplementation on biophysical parameters and chilling sensitivity of ewe oocytes. Mol. Reprod. Dev. 61, 271-278. 